\title{
JUVENILE DELINQUENCY \\ IN NOVEL CLOCKWORK ORANGE \\ BY ANTHONY BURGESS
}

\author{
Bena Yusuf Pelawi \\ English Department, Faculty of Letters, Universitas Kristen Indonesia \\ Jln. Mayjen Sutoyo No. 2, Cawang, Jakarta Timur \\ sylvie_surya@yahoo.co.id
}

\begin{abstract}
The study aimed to reveal the role of literary work, especially a novel in reflecting the social fenomena, the juvenile delinquency in the twentieth century. The data source was an English novel 'Clockwork Orange' written by Anthony Burgess. The research applied library research by using reflection theory introduced by Georg Lukacs. Analysis was presented in three parts, those were the identification of major character, social setting, and the reflection of juvenile delinquency. The findings were as follows. First, the major character was Alex as his hig intensity in all the events that build the whole story. Second, the social setting described the life of teenagers, especially the juvenile delinquency as social fenomena in society. Third, the role of literary work in revealing the problem above faced by the twentieth century society. Finally, it can be concluded that the literary work has played a very important role in revealing the social fenomena.
\end{abstract}

Keywords: juvenile delinquency, social fenomena, reflection theory, literary works

\begin{abstract}
ABSTRAK
Penelitian mendeskripsikan peran karya sastra dalam mencerminkan fenomena sosial, khususnya kenakalan remaja yang marak terjadi di dalam kehidupan masyarakat. Penelitian menggunakan metode studi pustaka dengan menggunakan teori refleksi oleh Georg Lukacs. Sumber data adalah sebuah novel berbahasa Inggris dengan judul Clockwork Orange, karya Anthony Burgess. Analisis dilakukan dalam 3 bagian, yaitu identifikasi karakter utama, seting sosial khususnya kenakalan remaja, dan peran karya sastra yang mampu memecahkan masalah kenakalan remaja di abad ke-20. Hasil penelitian menunjukkan bahwa pertama, tokoh utama dalam novel adalah Alex karena intensitas keterlibatannya dalam membangun keseluruhan cerita. Kedua, latar sosial dalam novel ini adalah kehidupan para remaja, khususnya tentang kenakalan remaja sebagai fenomena sosial yang terjadi pada abad ke-20. Ketiga, peran karya sastra, khususnya novel dalam mengungkap fenomena kenakalan remaja tersebut. Dengan demikian dapat disimpulkan bahwa karya sastra sangat berperan dalam mengungkapkan fenomena sosial yang terjadi di dalam kehidupan masyarakat.
\end{abstract}

Kata kunci: kenakalan remaja, fenomena sosial, teori refleksi, karya sastra 


\section{INTRODUCTION}

There seems to be no doubt that today many teenagers wish to express their freedom of speech by showing their emotions, anger, sadness, and happiness. They even directly and fearlessly express their dislikes to their parents or elderly people. In a transitional stage of physical and psychological human development, called adolescence also known as the period of rebellion, a child who has reached puberty often shows a variety of emotions, keeps himself/herself away from the family, and they normally have a lot of problems, either at home, school, or in their neighborhood (Salagaev, 2003).

Today teenagers face different issues than their parents used to deal with. Some issues are the same, including peer pressures, shoplifting, alcohol, drugs use, and sex. Young children whose behavior deviates is also refereed to as socially defective children. They suffer from a mental defect caused by social influences that exist in society. According to Kartono (2010), juvenile delinquency is a deviant behavior committed by young people which is caused by a form of the social neglect.

Juvenile delinquency ialah perilaku jahat (dursila), atau kejahatan/kenakalan anak-anak muda; merupakan gejala sakit (patologis) secara sosial pada anak-anak dan remaja yang disebabkan oleh satu bentuk pengabaian sosial, sehingga mereka itu mengembangkan bentuk tingkah laku yang menyimpang. (Kartono, 2010:6)

Looking into the above-stated explanation, a fiction (novel) entitled $A$ Clockwork Orange describing almost entirely about juvenile delinquency which reflects a real life in a society is worth to be analyzed. Juvenile delinquency is participation in illegal behavior by children or teens or individuals who are younger than the legal age of majority. It is anti-social personality disorder under 18 . This is why habitual juvenile offenders diagnosed with conduct disorder are likely to exhibit signs of antisocial personality disorder early in life and then as they mature. Some times these jeveniles reach maturation and they develop into career criminals.

Juvenile delinquents who have recurring encounters with the criminal justice system, or in other words those who are life-course-persistent offenders, are sometimes diagnosed with conduct disorders because they show a continuous disregard for their own and others safety and/or property. Once the juvenile continues to exhibit the same behavioral patterns and turns eighteen he is then at risk of being diagnosed wih antisocial personality disorder and much more prone to become a seious criminal offender. One of the main components used in diagnosing an adult with antisocial personality disorder consists of presenting documented history of conduct disorder before the age of 15 . (Wikipedia, n.d.)

The research conducted on the basis of the reflection theory by Georg Lukacs to reveal that juvenile delinquency in the 20th century as reflected in the novel 'A Clockwork Orange' by Anthony Burgees.

This research framework used reflection theory of Georg Lukacs. The reflection theory actually had been around since the time of Aristotle in the 19th century and continued to grow. Reflection theory was introduced by Georg Lukacs, a philosopher from Hungary. He created a theory of reflection that saw a literary work as a reflection from the society as by reading the text closely, so that we found out the writer's idea, imagination and life experience. He pointed that a literary work as knowledge about reality in condition and conflict that happened in society. The reality reflected through the literary work.

Based on Lukacs view, reflection theory has a whole characteristic, to reflect means to frame a mental structure transposed into words. He said the novel reflects reality not only in the surface appearance, but also giving us a true, more complete, more vivid, and more dynamic reflection of reality.

Lukacs' use of the term 'reflection' is characteristic of his work as a whole. Rejecting the 'naturalism' of the recent European novel, he returns to the old realist view that the novel reflects reality, not by rendering its mere surface appearance, but by giving us 'a truer, more complete, more vivid and more dynamic reflection of reality'. To 'reflect' is 'to frame a mental structure' transposed into words. (Selden, Widdowson, \& Brooker, 2005:87)

He also said that a novel might conduct a reader towards a more concrete insight into reality because a literary work reflected not individual phenomena in solation, but the full process of life, however, the reader was always aware that the work was not itself reality but rather a special form of reflecting reality.

Lukacs would say that a reflection may be more or less concrete. A novel may conduct a reader 'towards a more concrete insight into reality', which transcends a merely common-sense apprehension of things. A literary work reflects not individual phenomena in isolation, but 'the full process of life'. However, the reader is always aware that the work is not itself reality but rather 'a special form of reflecting reality'. (Selden, Widdowson, \& Brooker, 2005:87)

Generally Lukacs reflects an objectiive reality in the literary work and brings the three dimentional concept as the essence of realism. He also meantions 'the reflection model' in his work as the literature work that reflects the true reality, which is more complete, alive and dynamic.

\section{METHOD}

This descriptive-qualitative research is an embedded-case study. The source data for this study consist of documents selected with purposive sampling technique trough library research. The document referred to an English novel "A Clockwork Orange" written by Anthony Burgees. The research data were collected and analyzed using data analysis technique. The problems of this research were the main/major character, social setting, and the reflection of juvenile delinquency in a novel. Based on the aim of the research, the analysis is presented in three parts. They are the identification of major character, 
the analysis of social setting, and the reflection of juvenile delinquency in the novel A Clockwork Orange by Anthony Burgees.

\section{RESULTS AND DISCUSSION}

In this chapter, the theory that is used is reflection theory by Georg Lukacs. It is used to reveal the juvenile delinquency in a literary work, it is a novel ' A Clockwork Orange" written by Anthony Burgees. The analysis is divided into three sections: the major character, the social setting, and the reflection of juvenile delinquency fenomena in a literary work.

\section{The Major Character}

A major character is an important figure at the center of the story's action or theme (Di Yanni, 2000:35). It means the major character is the character that has high intensity in all the events that build the story. In this novel, the major character is Alex as he is always involved in the whole story, from the beginning until the end of it. It is identified in the following events: (1) Alex and his three friends like to get together in the bar; (2) Alex and his friends commit certain crimes; (3) Alex and his friends use mask when committing crimes; (4) Alex and his friends get involved in the gang fight; (5) Alex and his friends steal a car; (6) Alex and his friends get in a house and torture the owner; (7) Alex rapes two young girls; (8) Dim and Georgie dissatisfaction of Alex leadership; (9) Alex is betrayed by Dim and makes him arrested by the police; (10) Alex is put behind bars for fourteen years; (11) Alex has unpleasant experiences in prison; (12) Alex joins in a program to shorten his sentence; (13) Alex is freed from the prison because of the treatment program; (14) Alex has a problem with his family; (15) Alex meets with his victim; (16) Alex meets with his old enemy Dim and Billyboy; (17) Alex accidentally returns to a place where the police arrested him; (18) Alex met with his old friend Pete at a bar; (19) Alex wants to be a good person.

Based on the above events, it is clearly seen that Alex is the major character in this novel as he has the highest intensity involvement in events from the beginning to the end of the story that builds the story. It means that without Alex's involvement in the story, the novel will not be possible.

\section{The Social Setting}

Social setting involves description of society, social group with their behavior, habits, culture, lifestyle, language, etc., as the background of the event (Kenny, 1996:44-45). The social setting of the novel 'A Clockwork Orange' is the juvenile delinquency committed by a 15year-old boy and his friends in a small town in England. To identify the social setting in this novel, the analysis will be focused on the juvenile delinquency of Alex as the major character.

\section{Robberies}

They have a lot of money in their pocket. With the gang, they rob an old man's money, mock, and hit him violently. And they share the money with the members of the gang.

Our pocket were full of deng, so there was no real need from the point of view of crasting any more pretty polly to tolchock some old veck in an alley and viddy him swim in his blood while we counted the takings and divided by four, ... (ACO: 4)

\section{Car Thefts}

They go to the theatre park downtown to steal a car. They see very good cars. Their eyes spot at a very good condition of Durango '95. They have a clever way to steal a car, so they can easily get into the car. They start the car, drive a way, but nobody notices them taking off.

The autos parked by the sinny weren't all that horrorshow, crappy starry veshches most of them, but there was a newish Durango 95 that I thought might do. Georgie had one of these polycleft, as they called them, on his keyrin, so we were soon aboard - Dim and Pete at the back, puffing away lordly at their cancers - and I turned on the ignition and started her up and she grumbled away real horrorshow, a nice warm vibraty feeling grumbling all through your guttiwuts. Then I made with the noga, and we back out lovely, and nobody viddied us take off. ... (ACO: 22).

\section{Rapes and Murders}

Alex gives two young girls some alcohol to drink until they get drunk badly and they finally lay down uncounsciously, and then Alex rapes them. Later on the girls awake after Alex has finished with them. They scream after knowing that they are naked and put their clothes on. They leave with anger and say that Alex is the beast.

But they were both very very drunken and could hardly feel very much. When the last movement had gone round for the second time with all the banging and creeching about joy joy joy joy, ... They were like waking up to what was being done to their malenky persons and saying that they wanted to go home and like I was a wild beast. ... They were creeching and going o wow ow as they put their platties on, and they were like punchipunching me with their teeny fists as I lay there dirty and nagoy and fair shagged and fagged on the bed. This young sonietta was creeching : "Beast and hateful animal. (ACO: 51)

They get into a shop owned by Mrs. Slouse. She is frightened of Alex and his friends, so she is hiding behind the curtain. Alex finds her and sexually harasses her. Mrs. Slouse struggles and fights back. Alex beats her with a balance scale and hits her with a crowbar until her head bleeds (ACO: 12-13).

They also rape a woman in a shop and mess up everything inside the shop. They commit the crime not for money but for fun. They are always satisfied after doing it. "... nor to do the ultra-violent on same shivering starry grey-haired ptitsa in a shop and go smecking off with the till's guts. But as they say, money isn't everything. ..." (ACO: 4)

\section{Persecutions}

They come across an old man and mock him unpleasantly. They hold his hands and open the man's mouth widely and then they pull out his false teeth and 
throw them onto the sidewalk. They beat, kick and bleed him, take off his clotches until completely naked. And then they give a hard kick and leave.

'You naughty old veck, you,' I said, and then we began to filly about with him. Pete held his rookers and Georgie sort of hooked his rot wide open for him and Dim yanked out his false zoobies, upper and lower. He threw these down on the pavement and then I treated to the old boot crush, ... so Georgie let go of holding his goobers apart and just let him have one in the toothless rot with his ringy fist, and that made the old veck start moaning a lot then, then out comes the blood, my brothers, real beautiful. So all we did then was to pull his outer platties off, stripping him down to his vest and long underpants, ... and then Pete kicks him lovely in his pot, and we let him go. (ACO: 9-10).

Alex and his friends also persecute a couple, and when the couple beg for mercy,Alex and his friends ignore it. They even laugh and grind over the boot on them. (ACO: 38)

\section{Juvenile Delinquency Reflected in 'A Clockwork Orange'.}

The story begins with a gang of young boys; Alex, Dim, Pete, and Georgie. They like to hang out and commit criminals together. Alex is a fifteen-year-old boy who leads the gang. They spend times in a bar, plan their unlawful actions. They drink and consume drugs.

There was me, that is Alex, and my three droogs, that is Pete, Georgie, and Dim. Dim being relly dim, and we sat in the Korova Milkbar making up our rassoodocks what to do with the evening., ... The Korova Milkbar was a milk plus mesto, and you may, O my brothers, ... Well, what they sold there was milk plus something else. They had no licence for selling liquor, but there was no law yet against prodding some of the new veshcesh which they used to put into the old maloko, so you could peet it with vellocet or synthemecs or drencrom or one or two other veshches which would give you a nice quiet horrorshow fifteen minutes admiring Bog and All His Holy Angels and Saints in your left shoe with lights bursting all over your mozg. Or you could peet milk with knives in it, as we used to say, and this would sharpen you up and make you ready for a bit of dirty twenty-to-one, and that was what we were peeting this evening I'm starting off the story with. (ACO: 2-3)

Alex and his friends begin their unlawful actions by robbing and mistreating an old man. They rob to get a lot of money than divide the money among them and waste it together in a bar.

Out pocket were full of deng, so there was no real need from the point of view of crasting any more pretty polly to tolchock some old veck in an alley and viddy him swim in his blood whilewe counted the takings and divided by four, nor to do the ultraviolent on same shivering starry grey-haired ptitsa in a shop and go smecking off with the till's guts.
But as they say, money isn't everything. (ACO: 4)

Alex and his friends break into store. Alex's friends mess up everything insidethe store while Alex is beating and kicking the owner. They intimidate the owner's wife and sexually assault her.

Then you could shooshy panting and snoring and kicking behind the curtain and veshches falling over and swearing and then glass ging smash smash smash. Mother Slouse, the wife, was sort of froze behind the counter. We could tell she would creech murder given one chance, so I was round that counter very skorry and had a hold of her, and horrorshow big lump she was too, all nucking of scent and with flip flop big bobbing groodies on her. ... Well, then she had to be tolchocked proper with one of the wrights for the scale ... So we had her down on the floor and a rip of her platties for fun and gentle bit of the boot to stop her moaning. (ACO: 13)

Alex and his friends fight against another gang leader, named Billyboy. It begins when Billyboy wants to rape a girl, but the girl escapes because Alex and his friends come and ruin it. They mock and challenge each other and then start fighting.

Billyboy and his droogs stopped what they were doing, which was just getting ready to perform something on a weepy young devotchka they had there, not more than ten, she creeching away but with her platties still on, ... They'd probably just been doing the dirty slovo part of the act before getting down to a malenky bit of ultra-violence. When they viddied us a-coming they let go of this boo-hooing little ptitsa, ... Smiling very wide and droogie: How art thou, thou glooby bottle of cheap stinking chip-oil? Come and get one in the yarbles, if you have any yarbles, you eunuch jelly, thou,' And then we started ... (ACO: 18-19)

Alex leads his friends to go downtown and then to the theatre park to find and steal a car. They have their own technique to steal a car, so they can easily steal it with no one notices it.

The autos parked by the sinny weren't all that horrorshow, crappy starry veshches most of them, but there was a newish Durango 95 that I thought might do. Georgie had one of these polycleft, as they called them, on his keyring, so we were soon abroad - Dim and Pete at the back, puffing away lordly at their cancers --- and I turned on the ignition and started her up and she grumbled away real horrorshow, a nice warm vibraty feeling grumbling all through your guttiwuts. Then I made with the noga, and we back out lovely, and nobody viddied us take off. (ACO: 22)

Alex and his friends break into a house and persecute the house's owner. The house is owned by an author of 'A Clockwork Orange' name F.Alexander. They mess up the house, persecute the owner, rape the wife and let the husband see them. After they are satisfied, they let 
them alive in suffer.

While he filled with the author of A Clockwork Orange, making his listo all purple and drippping away like some very special sort of a juicy fruit. ..., Who was still creech creech creeching away in very horrorshow four-in-a-bar, locking her rookers from the back, while I ripped away at this and that and the other, the other going haw haw still, and real good horrorshow groodies they were that then exhibited their pink glazzies, $\mathrm{O}$ my brother ... Then after me it was right old Dim should have this turn, ... Then there was a changeover, Dim and me grabing the slobbering writer veck who was past struggling really, only just coming out with slack sort of slovos liek he was in the land in a milk plus bar, and Pete and Georgie had theirs. ... The writer veck and his zheena were not really there, bloody and torn and making noises. But they'd live. (ACO: 27-28)

The corrective school named P.R. Deltoid knows about what Alex and his friends have badly done. The corrective school has also reminded Alex not to get involved in a bad community. Alex ignires the corrective school's advice. Alex still rapes two girls, instead. He takes them into his room and gives alcohol to make them get drunk; in the meantime, Alex uses the opportunity to rape them.

But they were both very very drunken and could hardly feel very much. When the last movement had gone round for the second time with all the banging and creeching about joy joy joy joy, these two young ptitsas were not acting the big lady sophisto no more. They were like waking up to what was being done to their malenky persons and saying that they wanted to go home and like I was a wild beast. (ACO: 51)

Alex and his friends continue their criminal conducts. They plan to rob a house. Georgie advises them to rob the house because he knows that there is only a woman and her cats in that house. And he knows there is a lot of jewelry in the house.

'It was this house, see,' said Georgie. 'The one with the two lamps outside. The one with the gloopy name, like.'

'What gloopy name?'

'The Mantion or the Manse or some such piece of gloop. Where this very starry ptitsa lives with her cats and all this very starry valuable veshches.'

'Such as?'

'Gold and silver and like jewels. It was Will the English who like said.' (ACO:60-61)

Alex and his friends break into a house that they call it 'The Mantion or the Manse'. They mess up the house and Alex confronts the owner of the house. Alex beats her mercilessly until she bleeds and is uncounscious.

'Well, how lovely and all for me. But ittying towards it with my glazzies like full on it and my greedy rooker held out, I did not see the milk saucers on the floor and into one I went a short of lost balance. 'Whoops', I said, trying to steady, but this old ptitsa had come up behind me very sly and with great skorriness for her age and then she went crack crack on my gulliver with a bit of a stick. ... And then she was going crack crack again, saying; "Wretched little slummy bedbug, breaking into real people's houses, ... So then I got real bezoomy myself, brohers, and hit out of them, ... And upper with the little malenky like silver statue and cracked her a fine fair tolchock on the Gulliver and that shut her up real horrorshow and lovely. (ACO: 68-69)

From the analysis above, it is clearly shown that juvenile delinquency is unveiled in the novel 'A Clockwork Orange' by Anthony Burgess. Alex, a fifteen -year-oldboy as a major character and his friends convincingly have indicated that they commit juvenile delinquency.

\section{CONCLUSION}

The content of the novel portrays Alex's life. He is the subject who commits juvenile delinquency. All the events in the story show that Alex gets significant involvement in the juvenile delinquency. Alex has commited crimimal acts since in his early age, fifteen years old. He is the leader of a gang, together with his he commits criminal acts, such as robberies, auto theft, persecutions, rapes and murders. Based on the above analysis, this research concludes that juvenile delinquency is reflected in the novel 'A Clockwork Orange' by Anthony Burgess.

\section{REFERENCES}

Burgess, A. ( 2012). A Clocwork Orange. New England: W.W. Norton.

Di Yanni, R. (2000). Fiction: An Introduction. United States of America: McGraw-Hill Companies.

Kartono, K. (2010). Patologi Sosial 2: Kenakalan Remaja. Jakarta: Raja Grafindo Persada.

Kenny, W.(1996). How to Analyze Fiction. New York: Random House.

Salagaev, A.( 2003). World Youth Report, The Global Situation of Young People, Jevenile Delinquency. New York: Random House.

Selden, R., Widdowson, P., \& Brooker, P. (2005). A Reader's Guide to Contemporary Literary Theory (5th ed). Great Britain: Pearson Education.

Wikipedia. (n.d). Juvenile Delinquency. Retrieved from http://en.wikipedia.org/wiki/Juvenile_delinquency 